\title{
ANALISIS SISTEM TRANSMISI DAN DISTRIBUSI AIR BERSIH PERUMDA AIR MINUM TIRTA JUNGPORO WILAYAH PELAYANAN IKK BATEALIT
}

\section{ANALYSIS OF CLEAN WATER TRANSMISSION AND DISTRIBUTION SYSTEM PERUMDA DRINKING WATER TIRTA JUNGPORO SERVICE AREA IKK BATEALIT}

\author{
Hadyan Yusrannastar $I^{1}$, Nurani Ikhlas ${ }^{2}$,Bimastyaji Surya Ramadan ${ }^{2}$ \\ ${ }^{1}$ Departemen Teknik Lingkungan, Fakultas Teknik, Universitas Diponegoro JL. Prof, H. Sudarto, SH \\ Tembalang, Semarang, Indonesia, Email : yusrannastar@gmail.com \\ ${ }^{2}$ Departemen Teknik Lingkungan, Institut Teknologi Pembangunan Surabaya, \\ Surabaya 60188, Email : nurani.ikhlas@gmail.com \\ ${ }^{3}$ Departemen Teknik Lingkungan, Fakultas Teknik, Universitas Diponegoro JL. Prof, H. Sudarto, SH \\ Tembalang, Semarang, Indonesia, Email : bimastyaji@live.undip.ac.id
}

\begin{abstract}
ABSTRAK
Sistem penyediaan air bersih yang baik untuk masyarakat sangat dibutuhkan. Permasalahan air yang paling banyak dijumpai adalah tingkat pelayanan yang rendah dan kebocoran. PERUMDA Air Minum Tirta Jungporo merupakan perusahaan pemerintah daerah yang berfungsi menyediakan air bersih untuk masyarakat di Kabupaten Jepara. Sampai Desember 2019, angka pelayanan masih terbilang rendah dan kebocoran cukup tinggi. Pengumpulan data dilakukan dengan metode wawancara, observasi, dan dokumentasi. Data-data yang telah dikumpulkan akan dibandingkan dengan beberapa peraturan dan analisis hidrolika dilakukan dengan bantuan software EPANET 2.0. Salah satu wilayah pelayanan yang ada pada PERUMDA Air Minum Tirta Jungporo, IKK Batealit, memiliki cakupan pelayanan sebesar 33,9\% dan angka kebocoran sebesar 31,97\%. Dari hasil analisis diketahui bahwa tekanan air dan kecepatan pengaliran pada beberapa area masih belum memenuhi standar.
\end{abstract}

Kata kunci: Penyedian air bersih, PERUMDA Air Minum Tirta Jungporo, tingkat pelayanan, tingkat kebocoran

\begin{abstract}
A good supply of clean water system for people is very needed. Water problems that mostly found are low percentage of clean water service and water loss. PERUMDA Air Minum Tirta Jungporo is a regional government company that have duty to provide clean water for public in Jepara. Until Desember 2019, the level of clean water service is still low and water loss level is plenty high. Data are collected by doing interview, observation, and documentation. Data that had been collected will be compared to some regulations and hydraulic analysis will be analyzed with EPANET 2.0. One of the service region of PERUMDA Air Minum Tirta Junporo, Batealit Region, have percentage of clean water service about 33,9\% and water loss level is 31,97\%. From the result is known that water pressure and velocity of water are still not meet the standard.
\end{abstract}

Keyword: Clean water supply, PERUMDA Air Minum Tirta Jungporo, service level, water loss level 
Jurnal SEOI - Fakultas Teknik Universitas Sahid Jakarta

Vol 2 edisi 2 tahun 2020

\section{Pendahuluan}

Air merupakan sumber daya alam yang sangat penting bagi kehidupan manusia dalam kehidupan sehari-hari. Air berfungsi menjadi penopang dalam keberlangsungan hidup manusia dan makhluk hidup lainnya serta dapat meningkatkan kesejahteraan manusia. Penyediaan air bersih untuk masyarakat mempunyai peranan yang sangat penting dalam meningkatkan kesehatan masyarakat, untuk itu perlu diadakan suatu sistem yang dapat mengelola dan memberi persediaan air bagi masyarakat.

PERUMDA Air Minum Tirta Jungporo merupakan perusahaan pemerintah daerah yang berfungsi menyediakan air bersih untuk masyarakat di Kabupaten Jepara. Hal itu sesuai dengan visi perusahaan yaitu, menjadi penyedia air bersih dengan pelayanan prima didukung kinerja perusahaan yang sehat dan berwawasan lingkungan.

\section{Metodologi Penelitian}

Kerja Praktik dilaksanakan di PERUMDA Air Minum Tirta Jungporo terletak di Jalan Shima No. 12A Kecamatan Jepara, Kabupaten Jepara dengan wilayah pelayanan IKK Batealit. Waktu pelaksanaan kerja praktik dimulai dari tanggal 6 Januari 2020 sampai dengan tanggal 9 Februari 2020.

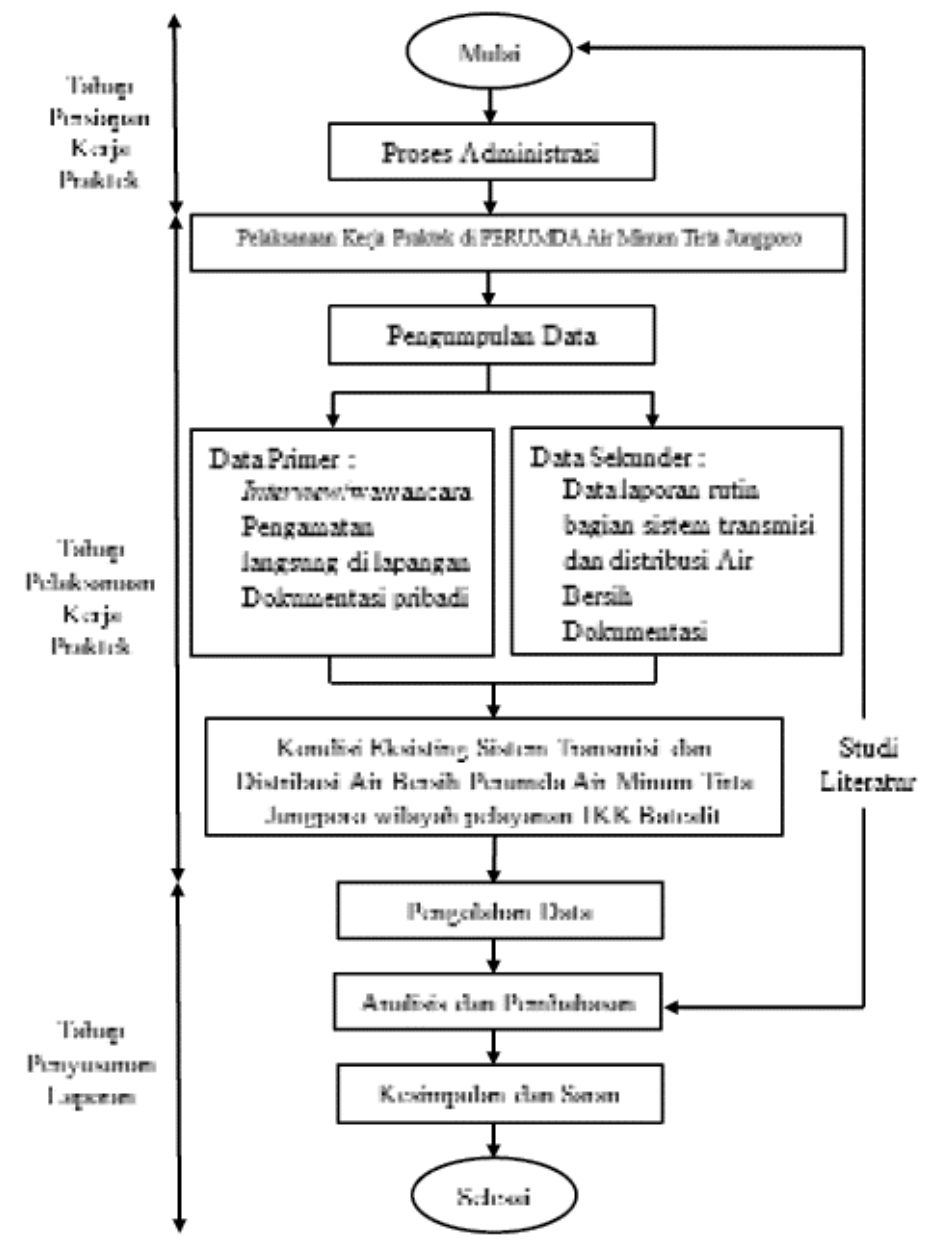

Gambar 1. Diagram Alir Kerja Praktik PERUMDA Air Minum Tirta Jungporo 


\section{Hasil dan Pembahasan}

\subsection{Unit Air Baku}

\subsubsection{Sumber Air Baku}

\subsubsection{Kuantitas Air Baku}

Pada wilayah pelayanan IKK Batealit sumber air baku yang dipakai didapat dari sumur dalam. Secara keseluruhan terdapat empat sumur dalam dengan rincian, dua sumur dalam dipompa ke reservoir dan dua sumur dalam lainnya didistribusikan langsung ke pelanggan. Untuk sumur dalam yang dipompa menuju reservoir, yaitu sumur Mindahan 1 dan sumur Mindahan 3, memiliki debit masing-masing sebesar 3 1/s dan 11 1/s. Kemudian sumur Mindahan 2 yang terletak di belakang kantor cabang memiliki debit sebesar 10 1/s dan sumur Bringin 1 memiliki debit 5 1/s.

Tabel 1. Debit Air Baku

\begin{tabular}{|c|c|c|}
\hline No. & Sumber Air Baku & Debit $(1 / \mathrm{s})$ \\
\hline 1 & Sumur Mindahan 1 & 3 \\
\hline 2 & Sumur Mindahan 3 & 11 \\
\hline 3 & Sumur Mindahan 2 & 10 \\
\hline 4 & Sumur Bringin 1 & 5 \\
\hline
\end{tabular}

Sumber: Bagian Teknik PERUMDA Air Minum Tirta Jungporo, 2020

\subsubsection{Kualitas Air Baku}

PERUMDA Air Minum Tirta Jungporo melakukan pemeriksaan tiap parameter setiap satu bulan sekali. Kualitas air baku sumur dalam di Batealit yang telah dibandingkan dengan baku mutu berdasarkan PERMENKES RI No. 492/MENKES/PER/IV/2010 tentang Persyaratan Kualitas Air Minum dan PERMENKES RI No. 416/MENKES/PER/IX/1990 tentang Syarat-syarat dan Pengawasan Kualitas Air dapat dilihat pada Tabel 2.

Dari hasil pemeriksaan air tersebut dapat disimpulkan bahwa kualitas air baku untuk wilayah pelayanan IKK Batealit memenuhi syarat yang telah ditetapkan. Baku mutu yang digunakan mengacu pada PERMENKES RI No. 492/MENKES/PER/IV/2010 tentang Persyaratan Kualitas Air Minum dan PERMENKES RI No. 416/MENKES/PER/IX/1990 tentang Syarat-syarat dan Pengawasan Kualitas Air.

Untuk parameter fisik dan kimia yang diukur sudah memenuhi persyaratan kualitas untuk air minum. Sedangkan, untuk parameter biologi, total coliform, tidak memenuhi persyaratan kualitas air minum yang diatur pada PERMENKES RI No. 492/MENKES/PER/IV/2010, yaitu sebesar 0 per $100 \mathrm{ml}$ sampel, namun masih memenuhi persyaratan untuk air bersih yang diatur pada PERMENKES RI No. 416/MENKES/PER/IX/1990, yaitu sebesar 10 per $100 \mathrm{ml}$ sampel untuk air perpipaan. Hal ini tidak perlu ditindaklanjuti karena masyarakat yang terlayani memasak air terlebih dahulu sebelum dikonsumsi. 
Jurnal SEOI - Fakultas Teknik Universitas Sahid Jakarta

Vol 2 edisi 2 tahun 2020

Tabel 2 Kualitas Air Baku untuk Wilayah Pelayanan IKK Batealit

\begin{tabular}{|c|c|c|c|c|}
\hline No & $\begin{array}{c}\text { Parameter Yang Perlu } \\
\text { Diperiksa }\end{array}$ & Satuan & Hasil & $\begin{array}{c}\text { Kadar Maksimal yang } \\
\text { Diperbolekan }\end{array}$ \\
\hline & FISIKA & & & \\
\hline 1 & Suhu & ${ }_{\mathrm{o}} \mathrm{C}$ & 25,2 & Suhu udara $\pm 3^{\circ} \mathrm{C}$ \\
\hline 2 & Warna & TCU & $<5$ & 15 \\
\hline 3 & $\mathrm{Bau}$ & - & $\begin{array}{l}\text { Tidak } \\
\text { Berbau }\end{array}$ & Tidak Berbau \\
\hline 4 & Rasa & - & $\begin{array}{l}\text { Tidak } \\
\text { Berasa }\end{array}$ & Tidak Berasa \\
\hline 5 & Kekeruhan & NTU & $<0,01$ & 5 \\
\hline 6 & DHL & $\mu$ hos & 200,6 & - \\
\hline \multirow[t]{2}{*}{7} & TDS & $\mathrm{mg} / \mathrm{l}$ & 133,5 & 500 \\
\hline & KIMIA & & & \\
\hline 8 & Derajat Keasaman & & 7,5 & $6,5-8,5$ \\
\hline 9 & Zat Organik & $\mathrm{mg} / \mathrm{l}$ & & 10 \\
\hline 10 & Karbondioksida agresif & $\mathrm{mg} / \mathrm{l}$ & & 0 \\
\hline 11 & Kesadahan $(\mathrm{CaCO} 3)$ & $\mathrm{mg} / \mathrm{l}$ & 26 & 500 \\
\hline 12 & Calsium & $\mathrm{mg} / \mathrm{l}$ & & - \\
\hline 13 & Magnesium & $\mathrm{mg} / \mathrm{l}$ & & - \\
\hline 14 & Alkalinitas & $\mathrm{mg} / \mathrm{l}$ & & - \\
\hline 15 & Carbonat & $\mathrm{mg} / \mathrm{l}$ & & - \\
\hline 16 & Bicarbonat & $\mathrm{mg} / \mathrm{l}$ & & - \\
\hline 17 & Besi & $\mathrm{mg} / \mathrm{l}$ & 0,04 & 0,3 \\
\hline 18 & Fluorida & $\mathrm{mg} / \mathrm{l}$ & 0,5 & 1,5 \\
\hline 19 & Mangan & $\mathrm{mg} / \mathrm{l}$ & 0,068 & 0,4 \\
\hline 20 & Tembaga & $\mathrm{mg} / \mathrm{l}$ & & 2 \\
\hline 21 & Seng & $\mathrm{mg} / \mathrm{l}$ & 0,01 & 3 \\
\hline 22 & Klorida & $\mathrm{mg} / \mathrm{l}$ & 23 & 250 \\
\hline 23 & Sulfat & $\mathrm{mg} / \mathrm{l}$ & 3 & 250 \\
\hline 24 & Amonia & $\mathrm{mg} / \mathrm{l}$ & & 1,5 \\
\hline 25 & Nitrat & $\mathrm{mg} / \mathrm{l}$ & 0,66 & 50 \\
\hline 26 & Nitrit & $\mathrm{mg} / \mathrm{l}$ & 0,06 & 3 \\
\hline 27 & Kromium & $\mathrm{mg} / \mathrm{l}$ & 0,005 & 0,05 \\
\hline 28 & Sianida & $\mathrm{mg} / \mathrm{l}$ & 0,006 & 0,07 \\
\hline \multirow[t]{2}{*}{29} & Cadmium & $\mathrm{mg} / \mathrm{l}$ & & 0,003 \\
\hline & BIOLOGI & & & \\
\hline 30 & Total Coliform & $\mathrm{CFU} / 100 \mathrm{ml}$ & $<3$ & 10 per $100 \mathrm{ml}^{* *}$ \\
\hline 31 & E. Coli & $\mathrm{CFU} / 100 \mathrm{ml}$ & & \\
\hline
\end{tabular}

Sumber: 1. Bagian Teknik PERUMDA Air Minum Tirta Jungporo, 2020

2. *PERMENKES RI No. 492/MENKES/PER/IV/2010

3. **PERMENKES RI No. 416/MENKES/PER/IX/1990 


\subsubsection{Kontinuitas Air Baku}

Air baku untuk air bersih harus dapat diambil terus menerus dengan fluktuasi debit yang relatif tetap, dan sampai kepada pelanggan selama 24 jam per hari. Pompa untuk mengambil air baku yang ada pada wilayah pelayanan IKK Batealit rata-rata bekerja selama 22 jam setiap harinya untuk menghindari overheat pada pompa dan memperpanjang umur pompa. Hal ini mengakibatkan air tidak dapat mengalir selama 24 jam di beberapa area sehingga persyaratan kontinuitas tidak tercapai. Untuk itu, pompa diistirahatkan pada tengah malam, dimana pada waktu tersebut penggunaan air oleh pelanggan sangat minimum sehingga tidak tercapainya kontinuitas ini tidak begitu mengganggu pelanggan.

\subsubsection{Sistem Transmisi}

\subsubsection{Analisis jalur Pipa Transmisi}

Jalur pipa transmisi dialiri oleh debit total sebesar 14 1/s dan memiliki diameter sebesar $150 \mathrm{~mm}$. Jarak antara sumber air baku dari sumur Mindahan 1 ke reservoir adalah $6 \mathrm{~m}$ dan dari sumur Mindahan 3 ke reservoir adalah $504 \mathrm{~m}$. jenis pipa yang digunakan adalah ACP/GIP dan PVC. Sistem pengaliran air pada PERUMDA Air Minum Tirta Jungporo wilayah pelayanan IKK Batealit dari air baku hingga ke reservoir menggunakan sistem pemompaan dikarenakan elevasi reservoir lebih tinggi daripada elevasi air baku yang berupa sumur dalam.

Tabel 3. Evalasi Lokasi pada Sistem Transmisi

\begin{tabular}{|c|c|}
\hline Lokasi & Elevasi(mdpl) \\
\hline Sumur Dalam Mindahan 1 & 182 \\
\hline Sumur Dalam Mindahan3 & 178 \\
\hline Reservoir Batealit & 182 \\
\hline
\end{tabular}

Sumber: Bagian Teknik PERUMDA AirMinum Tirta Jungporo, 2020

\subsubsection{Kelengkapan Pipa Transmisi}

Kelengkapan yang dapat ditemukan pada jalur pipa transmisi adalah manometer, water meter (stand meter), check valve dan gate valve. Kelengkapan pada jalur pipa transmisi wilayah pelayanan IKK Batealit bisa dikatakan kurang lengkap, karena tidak terdapat beberapa perlengkapan penting yang tercantum dalam Permen PU No. 18 Tahun 2007.

Tabel 4. Perlengkapan Sistem Transmisi

\begin{tabular}{lc}
\hline \multicolumn{1}{c}{ Perlengkapan Penting dan Pokok dalam } & $\begin{array}{c}\text { Kelengkapan Jalur Pipa Transmisi Wilayah } \\
\text { Sistem Transmisi }\end{array}$ \\
\hline Katup pelepas udara & - \\
Katup pelepas tekanan & - \\
Katup penguras & - \\
Katup ventilasi & - \\
\hline
\end{tabular}

Sumber: Permen PU No. 18 Tahun 2007

\subsubsection{Analisis Pompa Transmisi}


Air yang berasal dari sumur Mindahan 1 dan sumur Mindahan 3 dialirkan ke reservoir terlebih dahulu dengan menggunakan pompa berkapasitas masing-masing 5 1/s dan 12 1/s, baru kemudian didistribusikan. Beberapa area pelanggan dapat terlayani selama 24 jam karena sebelumnya air dari sumber air baku sudah ditampung terlebih dahulu di reservoir yang pompanya beroperasi selama 22 jam.

Head pompa pada sumur Mindahan 3 adalah 90 m, sedangkan head yang dibutuhkan adalah 65,7 m, sehingga masih terdapat cukup sisa tekan sebesar 24,3 m untuk menaikkan air dari sumur Mindahan 3 ke reservoir.

\subsubsection{Analisis Hidrolika Pipa Transmisi}

Analisis Hidrolika digunakan untuk memastikan air dapat mengalir secara gravitasi. Hal ini ditandai dengan nilai EGL dan HGL lebih dari elevasi tanah. Nilai ini didapatkan setelah melakukan analisis hidrolika menggunakan rumus Hazen- William.

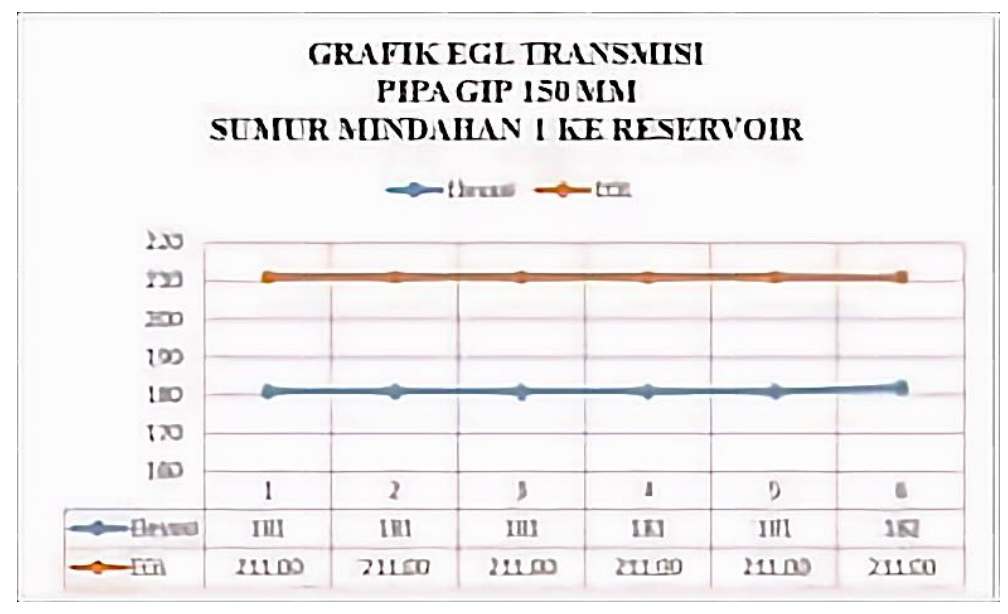

Gambar 2. Grafik EGL Transmisi Mindahan 1

Sumber: Analisis Penulis, 2020

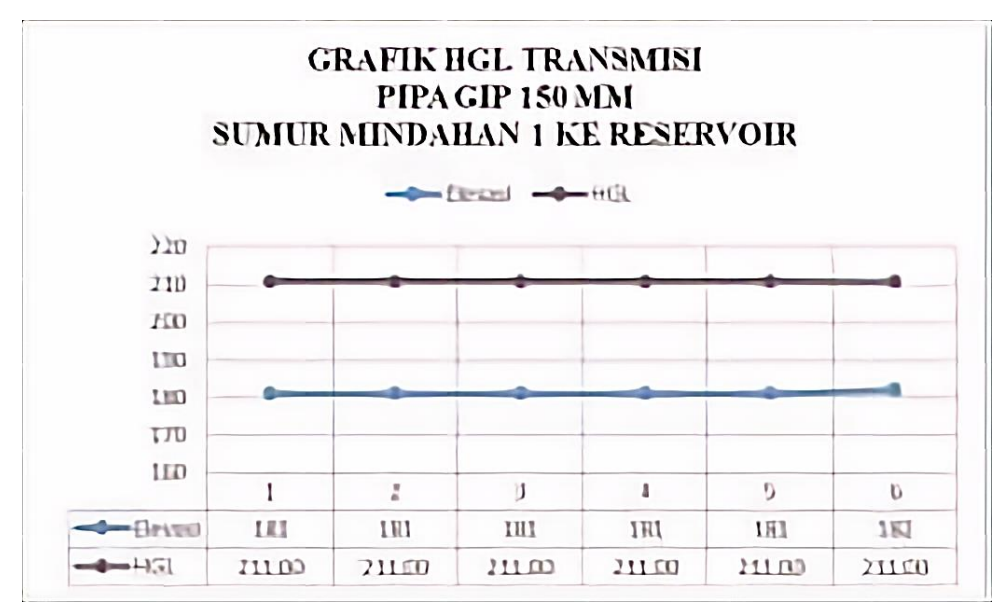

Gambar 3. Grafik HGL Transmisi Mindahan 1

Sumber: Analisis Penulis, 2020 
Jurnal SEOI - Fakultas Teknik Universitas Sahid Jakarta

Vol 2 edisi 2 tahun 2020

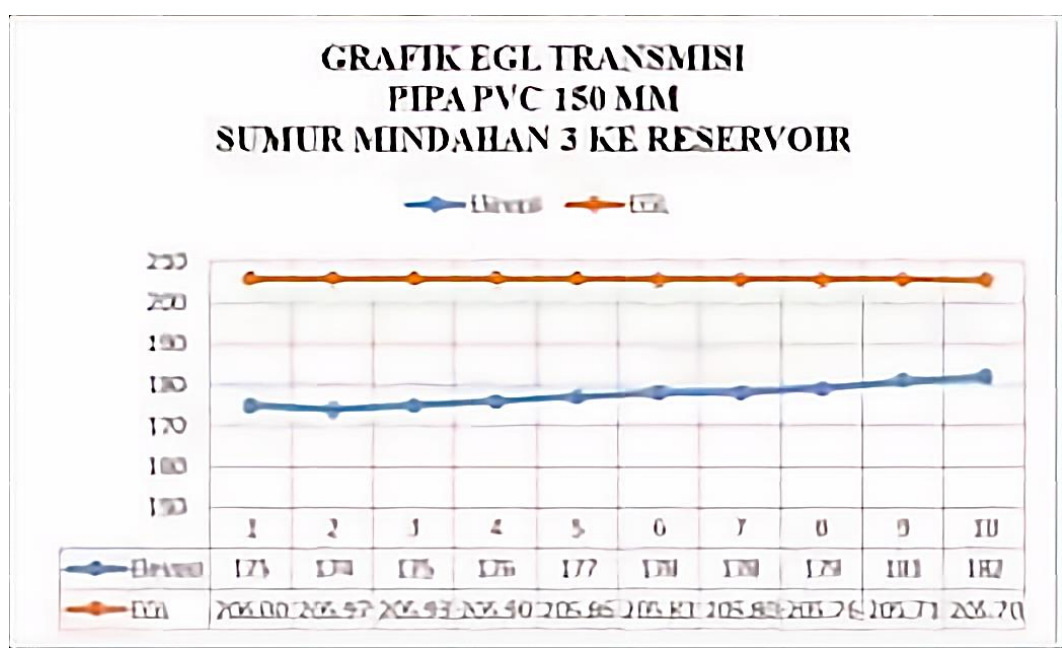

Gambar 4. Grafik EGL Transmisi Mindahan 3

Sumber: Analisis Penulis, 2020

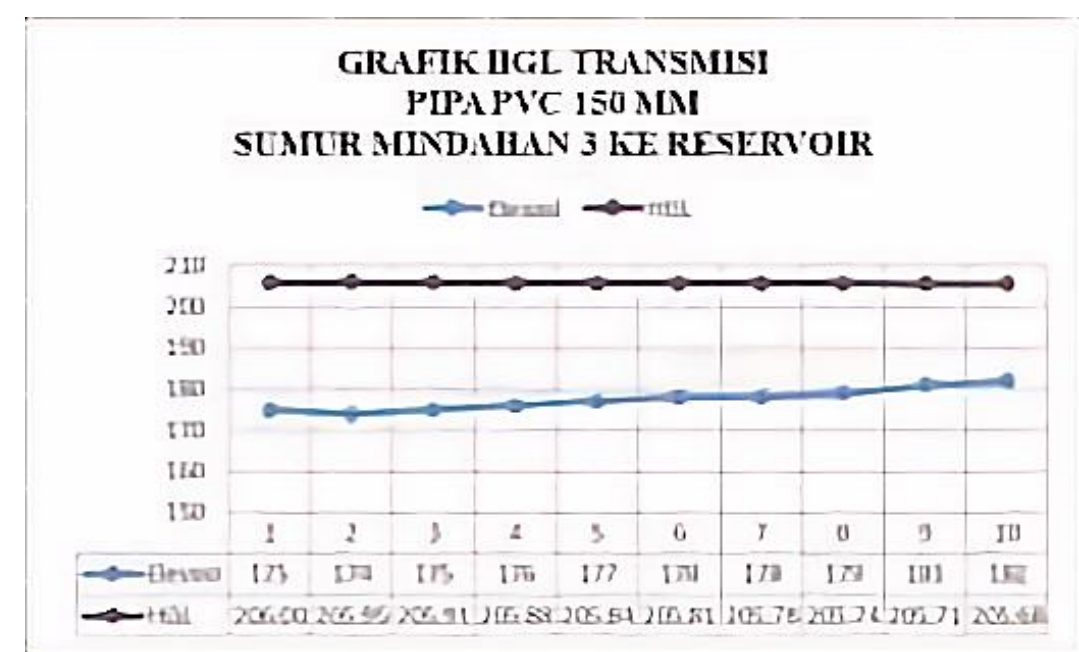

Gambar 5. Grafik HGL Transmisi Mindahan 3

Sumber: Analisis Penulis, 2020

Dari grafik terlihat bahwa nilai EGL-HGL perpipaan transmisi yang bersumber dari sumur Mindahan 1 dan sumur Mindahan 3 setelah dipompa menuju reservoir berada di atas elevasi tanah. Hal ini menurut Permen PUPR Nomor 27 Tahun 2016 menunjukkan bahwa air di perpipaan transmisi dapat mengalir.

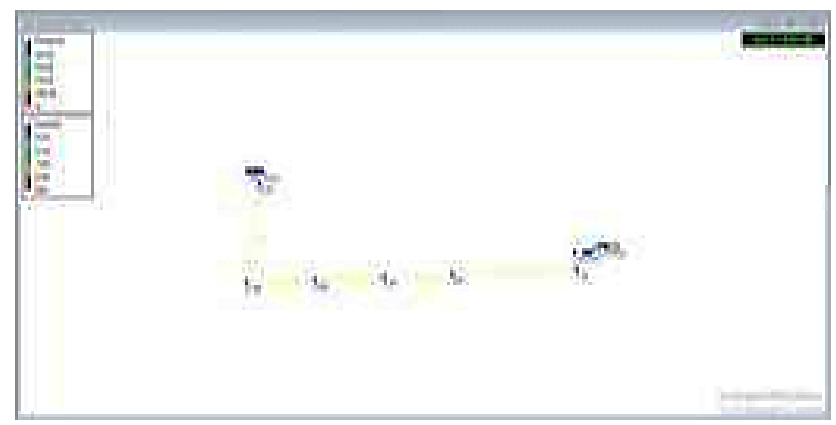

Gambar 6. Analisis EPANET 2.0 Pipa Transmisi

Sumber: Analisis Penulis, 2020 


\subsection{Unit Distribusi}

Air yang didistribusikan pada wilayah pelayanan selain bersumber dari reservoir yang menggunakan sistem pengaliran secara gravitasi juga berasal dari sumur Mindahan 2 dan sumur Bringin 1 yang menggunakan pompa. Pompa yang digunakan pada sumur Mindahan 2 berkapasitas 10 l/s dan Bringin 1 berkapasitas 7,5 1/s rata-rata beroperasi selama 22 jam tanpa ditampung di reservoir dan langsung didistribusikan ke pelanggan.

Sistem yang digunakan di wilayah pelayanan IKK Batealit adalah gabungan antara branch dan loop. Jenis perlengkapan yang terdapat pada jalur distribusi wilayah pelayanan IKK Batealit adalah gate valve yang berfungsi untuk membuka dan menutup aliran air dalam pipa, air valve, reducer dan jembatan pipa.

\subsubsection{Tingkat Pelayanan, Jumlah Pelanggan dan Kebutuhan Air}

Pelanggan PERUMDA Air Minum Tirta Jungporo yang terdapat pada wilayah pelayanan IKK Batealit yang terdiri dari 5 kelurahan adalah 2982 SR sedangkan total jumlah penduduk pada IKK tersebut sebanyak 43984 jiwa sehingga tingkat pelayanan di Wilayah Pelayanan IKK Batealit sebesar 33,9\%.

Berikut merupakan Analisis dari perhitungan pemakaian air, dan tingkat pelayanan pada bulan Desember 2019.

Untuk rincian tingkat pelayanan adalah sebagai berikut:

$$
\begin{aligned}
& \text { Jumlah penduduk } \quad=43984 \text { jiwa } \\
& \text { Jumlah SR } \quad=2982 \\
& \text { Asumsi } 1 \mathrm{SR}=5 \text { jiwa } \\
& \% \text { Pelayanan }=\frac{\text { Jumlah penduduk terlayani }}{\text { Jumlah penduduk total }} \times 100 \% \\
& \% \text { Pelayanan }=\frac{2982 \times 5}{43984} \times 100 \% \\
& \% \text { Pelayanan }=33,9 \%
\end{aligned}
$$

Konsumsi air tiap orang

$$
\frac{\text { Total kebutuhan air }}{\text { Jumlah penduduk }}=\frac{1485 \mathrm{~m} 3 / \text { hari } \times 1000}{14525}=1021 / \text { orang/hari }
$$

Berdasarkan perhitungan, diketahui konsumsi per orang per hari di wilayah pelayanan IKK Batealit yaitu sebesar 102 1/orang/hari. Menurut Dirjen Cipta Karya, Kecamatan Batealit masuk kategori Kota Kecil karena jumlah penduduk diantara 20.000-100.000. Untuk kategori kota kecil sendiri, konsumsi air bersih per orang per hari pada sambungan rumah adalah $80-120$ liter/orang/hari.

\subsubsection{Kehilangan Air}

Kehilangan air dari sistem distribusi terdiri dari kebocoran fisik dan kebocoran administrasi. Sejauh ini yang dilakukan PERUMDA Air Minum Tirta Jungporo untuk menghitung kehilangan air adalah dengan mencari selisih antara debit air yang didistribusikan dengan debit air yang dikonsumsi oleh pelanggan, kemudian dibagi dengan jumlah debit air yang didistribusikan. 
Jurnal SEOI - Fakultas Teknik Universitas Sahid Jakarta

Vol 2 edisi 2 tahun 2020

Tabel 5. Data Kehilangan Air

\begin{tabular}{lc}
\hline \multicolumn{1}{c}{ Bulan } & \% \\
\hline Januari & 36.94 \\
Februari & 34.23 \\
Maret & 38.20 \\
April & 36.14 \\
Mei & 36.23 \\
Juni & 26.12 \\
Juli & 35.79 \\
Agustus & 33.39 \\
September & 25.12 \\
Oktober & 23.62 \\
November & 33.28 \\
Desember & 28.05 \\
\hline Rata-rata & $\mathbf{3 1 . 9 7}$ \\
\hline
\end{tabular}

Sumber: Bagian Teknik PERUMDA AirMinum Tirta Jungporo, 2020

Berdasarkan kriteria perencanaan Ditjen Cipta Karya Dinas PU 1996, kehilangan air seharusnya adalah 20-30\%. Namun pada kondisi eksisting, kehilangan air rata-rata adalah $31,97 \%$ dan kehilangan air tertinggi adalah $38,20 \%$.

\subsubsection{Analisis Reservoir}

\subsubsection{Fluktuasi Pemakaian Air pada Jam Puncak dan Harian Maksimum}

Pemakaian air pada jam puncak adalah jumlah air terbanyak yang dimanfaatkan untuk keperluan domestik pada jam-jam tertentu dalam satu hari, sedangkan harian maksimum adalah jumlah air terbanyak yang dimanfaatkan untuk keperluan domestik pada hari-hari tertentu dalam satu Minggu.

Dalam perhitungan kali ini, faktor jam puncak dicari dengan menggunakan data primer. Berupa pengukuran meter air tiap jam selama 24 jam. Dari data tersebut, dicari penggunaan air paling besar dalam dalam satu hari kemudian dibagi dengan rata-rata penggunaan air tiap jamnya.

Tabel 6. Fluktuasi Pemakaian Ari Setiap Jam

\begin{tabular}{cccccc}
\hline No & Jam & Standmeter(1/s) & Standmeter $\left(\mathbf{m}^{\mathbf{3}} / \mathbf{j a m}\right)$ & \% & Fluktuasi(Pattern $)$ \\
\hline 1 & $00.00-01.00$ & 4 & 14.4 & 2.2 & 0.53 \\
2 & $01.00-02.00$ & 4 & 14.4 & 2.2 & 0.53 \\
3 & $02.00-03.00$ & 4 & 14.4 & 2.2 & 0.53 \\
4 & $03.00-04.00$ & 7 & 25.2 & 3.9 & 0.93 \\
5 & $04.00-05.00$ & 7 & 25.2 & 3.9 & 0.93 \\
6 & $05.00-06.00$ & 9 & 32.4 & 5.0 & 1.20 \\
7 & $06.00-07.00$ & 10 & 36 & 5.6 & 1.33 \\
8 & $07.00-08.00$ & 9 & 32.4 & 5.0 & 1.20 \\
9 & $08.00-09.00$ & 9 & 32.4 & 5.0 & 1.20 \\
\hline
\end{tabular}


Jurnal SEOI - Fakultas Teknik Universitas Sahid Jakarta

Vol 2 edisi 2 tahun 2020

\begin{tabular}{|c|c|c|c|c|c|}
\hline No & Jam & Standmeter( $(1 / \mathbf{s})$ & Standmeter $\left(\mathbf{m}^{3} / \mathbf{j a m}\right)$ & $\%$ & Fluktuasi(Pattern) \\
\hline 10 & $09.00-10.00$ & 9 & 32.4 & 5.0 & 1.20 \\
\hline 11 & $10.00-11.00$ & 7 & 25.2 & 3.9 & 0.93 \\
\hline 12 & $11.00-12.00$ & 8 & 28.8 & 4.4 & 1.07 \\
\hline 13 & $12.00-13.00$ & 9 & 32.4 & 5.0 & 1.20 \\
\hline 14 & $13.00-14.00$ & 8 & 28.8 & 4.4 & 1.07 \\
\hline 15 & $14.00-15.00$ & 9 & 32.4 & 5.0 & 1.20 \\
\hline 16 & $15.00-16.00$ & 8 & 28.8 & 4.4 & 1.07 \\
\hline 17 & $16.00-17.00$ & 9 & 32.4 & 5.0 & 1.20 \\
\hline 18 & $17.00-18.00$ & 9 & 32.4 & 5.0 & 1.20 \\
\hline 19 & $18.00-19.00$ & 9 & 32.4 & 5.0 & 1.20 \\
\hline 20 & $19.00-20.00$ & 9 & 32.4 & 5.0 & 1.20 \\
\hline 21 & $20.00-21.00$ & 8 & 28.8 & 4.4 & 1.07 \\
\hline 22 & $21.00-22.00$ & 5 & 18 & 2.8 & 0.67 \\
\hline 23 & $22.00-23.00$ & 5 & 18 & 2.8 & 0.67 \\
\hline 24 & $23.00-00.00$ & 5 & 18 & 2.8 & 0.67 \\
\hline \multicolumn{2}{|c|}{ Jumlah } & 180 & 648 & 100 & 24.00 \\
\hline \multicolumn{2}{|c|}{ Rata-rata } & 7.5 & 27 & 4.17 & 1.00 \\
\hline \multicolumn{2}{|c|}{ Maksimum } & 10 & 36 & 5.6 & 1.33 \\
\hline
\end{tabular}

Sumber: Bagian Teknik PERUMDA Air Minum Tirta Jungporo, 2020

- Penggunaan air maksimum $=10 \mathrm{l} / \mathrm{s}$

- Rata-rata penggunaan air per jam $=7,5 \mathrm{l} / \mathrm{s}$

- Faktor jam puncak $=\frac{10 \mathrm{l} / \mathrm{s}}{7,5 \mathrm{l} / \mathrm{s}}=1.33$

Perhitungan faktor harian maksimum menggunakan data primer. Yaitu data penggunaan air selama satu minggu dari wilayah pelayanan IKK Batealit. Dalam satu minggu dicari faktor harian maksimumnya. Dari perhitungan ini akan diperoleh angka faktor harian maksimum.

Tabel 7. Pemakaian Air Harian dalam Satu Minggu

\begin{tabular}{ccc}
\hline Tanggal & Flow $\left(\mathbf{m}^{\mathbf{3}}\right)$ & Pemakaiandalam Satu Hari $\left(\mathbf{m}^{\mathbf{3}}\right)$ \\
\hline 09 Februari 2020 & 537210 & - \\
10 Februari 2020 & 537383 & 173 \\
11 Februari 2020 & 537571 & 188 \\
12 Februari 2020 & 537756 & 185 \\
13 Februari 2020 & 537937 & 181 \\
14 Februari 2020 & 538126 & 189 \\
15 Februari 2020 & 538306 & 180 \\
16 Februari 2020 & 538491 & 185 \\
\hline Jumlah & & 1281 \\
\hline Rata-rata & & 183 \\
\hline Maksimum & & 189 \\
\hline
\end{tabular}

Sumber: Bagian Teknik PERUMDA AirMinum Tirta Jungporo, 2020 
Jurnal SEOI - Fakultas Teknik Universitas Sahid Jakarta

Vol 2 edisi 2 tahun 2020

Dari perhitungan diatas, dicari rata rata dalam satu hari

$\mathrm{Fhm}=\frac{\mathrm{Q} \max }{\mathrm{Q} \text { rata }- \text { rata }}$

Fhm $=\frac{189 \mathrm{~m} 3 / \text { hari }}{183 \mathrm{~m} 3 \text {,hari }}=1,03$

Tabel 8. Kapasitas Penyimpanan Reservoir

\begin{tabular}{cccccc}
\hline No & Jam & \% & $\begin{array}{c}\text { \% } \\
\text { Inflow }\end{array}$ & $\begin{array}{c}\text { Selisih } \\
\text { Pemakaian }\end{array}$ & Akumulasi \\
\hline 1 & $0.00-01.00$ & 2.2 & 0 & -2.2 & -2.2 \\
2 & $01.00-02.00$ & 2.2 & 4.55 & 2.2 & 0 \\
3 & $02.00-03.00$ & 2.2 & 4.55 & 2.3 & 2.3 \\
4 & $03.00-04.00$ & 3.9 & 4.55 & 0.7 & 3.0 \\
5 & $04.00-05.00$ & 3.9 & 4.55 & 0.7 & 3.7 \\
6 & $05.00-06.00$ & 5.0 & 4.55 & -0.5 & 3.2 \\
7 & $06.00-07.00$ & 5.6 & 4.55 & -1.0 & 2.2 \\
8 & $07.00-08.00$ & 5.0 & 4.55 & -0.5 & 1.8 \\
9 & $08.00-09.00$ & 5.0 & 4.55 & -0.5 & 1.3 \\
10 & $09.00-10.00$ & 5.0 & 4.55 & -0.5 & 0.8 \\
11 & $10.00-11.00$ & 3.9 & 4.55 & 0.7 & 1.5 \\
12 & $11.00-12.00$ & 4.4 & 4.55 & 0.1 & 1.6 \\
13 & $12.00-13.00$ & 5.0 & 4.55 & -0.5 & 1.2 \\
14 & $13.00-14.00$ & 4.4 & 4.55 & 0.1 & 1.3 \\
15 & $14.00-15.00$ & 5.0 & 4.55 & -0.5 & 0.8 \\
16 & $15.00-16.00$ & 4.4 & 4.55 & 0.1 & 0.9 \\
17 & $16.00-17.00$ & 5.0 & 4.55 & -0.5 & 0.5 \\
18 & $17.00-18.00$ & 5.0 & 4.55 & -0.5 & 0 \\
19 & $18.00-19.00$ & 5.0 & 4.55 & -0.5 & -0.4 \\
20 & $19.00-20.00$ & 5.0 & 4.55 & -0.5 & -0.9 \\
21 & $20.00-21.00$ & 4.4 & 4.55 & 0.1 & -0.8 \\
22 & $21.00-22.00$ & 2.8 & 4.55 & 1.8 & 1 \\
23 & $22.00-23.00$ & 2.8 & 4.55 & 1.8 & 2.8 \\
24 & $23.00-00.00$ & 2.8 & 0 & -2.8 & \\
\hline & Jumlah & 100.00 & 100.00 & 0 & 27.9 \\
\hline & Rata-rata & 4.17 & 4.17 & 0 & 1.16 \\
\hline & Maksimum & 5.6 & 4.55 & 2.3 & 3.8 \\
\hline & Minimum & & & -2.8 & -2.2 \\
\hline
\end{tabular}

Sumber: Analisis Penulis, 2020

Dari hasil perhitungan diketahui angka maksimum dan minimum. Angka-angka tersebut kemudian digunakan untuk mencari kebutuhan reservoir sebenarnya.

1. \% Kebutuhan Reservoir

Akumulasi maksimum $=3,8 \%$

Akumulasi minimum $=-2,7 \%$

$\%$ kebutuhan reservoir $=[$ Akumulasi maksimum-Akumulasi minimum $]$

$\%$ kebutuhan reservoir $=3,8-(-2,7)$

$\%$ kebutuhan reservoir $=6 \%$ 
2. Kebutuhan Rata-rata (Q rata-rata)

Jumlah kebutuhan rata-rata adalah jumlah kebutuhan air setelah ditambah kehilangan air Q rata-rata $=$ Kebutuhan air + Kehilangan air

Kebutuhan air $=47987 \mathrm{~m}^{3} /$ bulan

Kebutuhan air $=18,511 / \mathrm{s}$

$\mathrm{Q}$ rata-rata $=18,511 / \mathrm{s}+(40 \% \times 18,51 / \mathrm{s})$

$\mathrm{Q}$ rata-rata $=25,91 \mathrm{l} / \mathrm{s}$

3. Kebutuhan Hari Maksimum (Q hm)

Kebutuhan hari maksimum adalah faktor harian maksimum (didapat dari hasil analisis fluktuasi pemakaian air pada hari maksimum) dikalikan dengan jumlah kebutuhan rata-rata.

$\mathrm{Q}$ harian maksimum $=$ Faktor hari maksimum $\times \mathrm{Q}$ rata-rata

$\mathrm{Q}$ harian maksimum $=1,03 \times 25,91 \mathrm{l} / \mathrm{s}$

$\mathrm{Q}$ harian maksimum $=26,68 \mathrm{l} / \mathrm{s}=2305,15 \mathrm{~m}^{3} / \mathrm{hari}$

4. Kebutuhan Jam Puncak (Q jp)

Kebutuhan jam puncak adalah faktor jam puncak (didapat dari hasil analisis fluktuasi pemakian air pada jam puncak) dikalikan dengan jumlah kebutuhan rata-rata.

$\mathrm{Q}$ jam puncak = faktor jam puncak $x \mathrm{Q}$ rata-rata

$\mathrm{Q}$ jam puncak $=1,33 \times 25,911 / \mathrm{s}$

$\mathrm{Q}$ jam puncak $=34,461 / \mathrm{s}$

5. Kebutuhan Reservoir

Kebutuhan reservoir sebenarnya adalah faktor pengali kebutuhan reservoir (didapat dari hasil analisis kebutuhan reservoir) dikalikan dengan kebutuhan harian maksimum. Reservoir mendapat supply air dari Irigasi Bendung Gerak Serayu dan Embung.

Volume Reservoir

Volume $=\%$ Kebutuhan reservoir $\times \mathrm{Q}$ hm

Volume $=6 \% \times 2305,15 \mathrm{~m}^{3} / \mathrm{hari}$

Volume $=138,3 \mathrm{~m}^{3} \approx 140 \mathrm{~m}^{3}$

Di lapangan, reservoir yang digunakan berkapasitas $350 \mathrm{~m}^{3}$.

\subsubsection{Analisis Hidrolika Pipa Distribusi}

Analisis Hidrolika digunakan untuk memastikan air dapat mengalir secara gravitasi. Hal ini ditandai dengan nilai EGL dan HGL lebih dari elevasi tanah. Nilai ini didapatkan setelah melakukan analisis hidrolika menggunakan rumus Hazen- William.

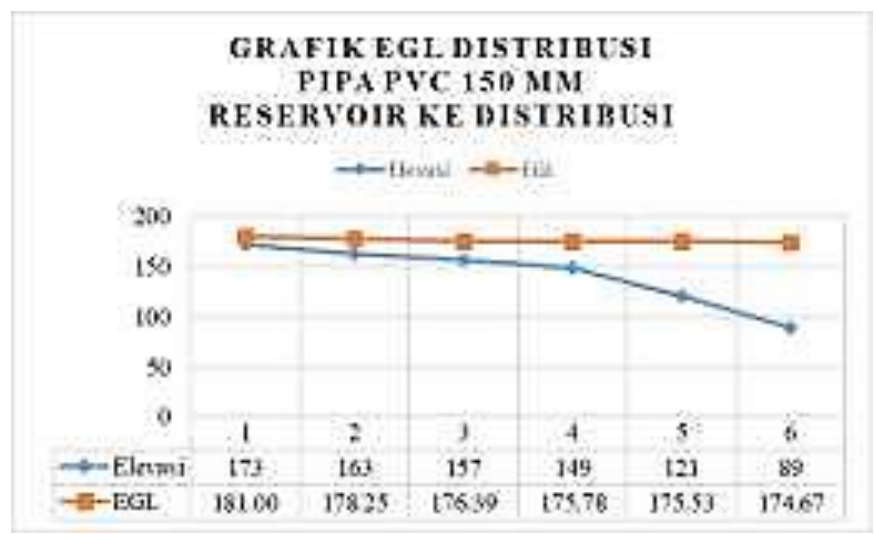

Gambar 7. Grafik EGL Distribusi Batealit

Sumber: Analisis Penulis, 2020 
Jurnal SEOI - Fakultas Teknik Universitas Sahid Jakarta

Vol 2 edisi 2 tahun 2020

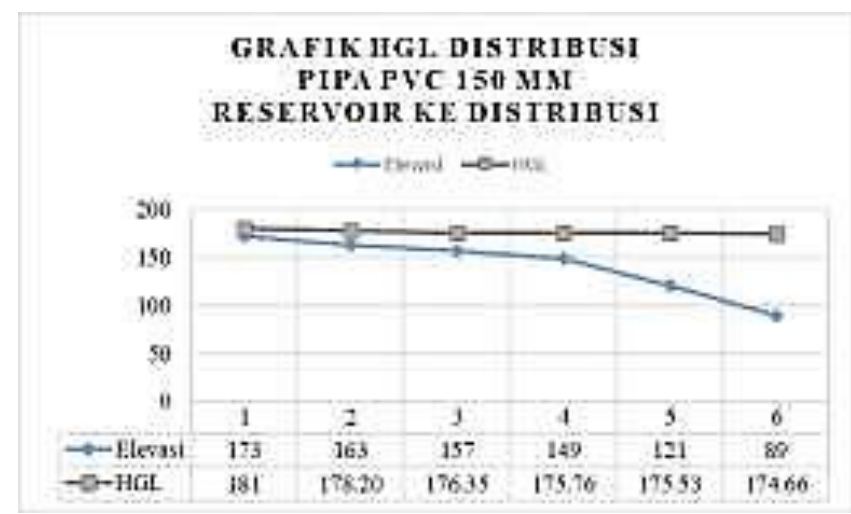

Gambar 8. Gambar HGL Distribusi Batealit

Sumber: Analisis Penulis, 2020

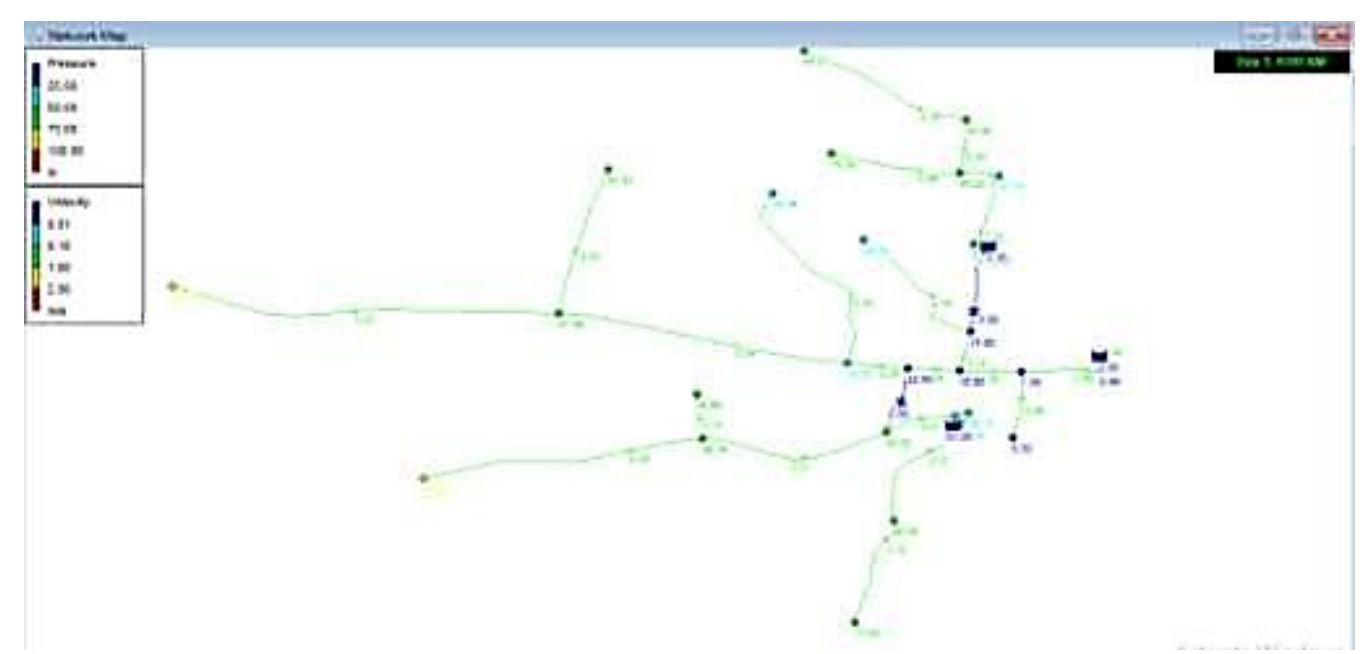

Gambar 9. Analisis EPANET 2.0 Pipa Distribusi pada Jam Puncak Sumber: Analisis Penulis, 2020

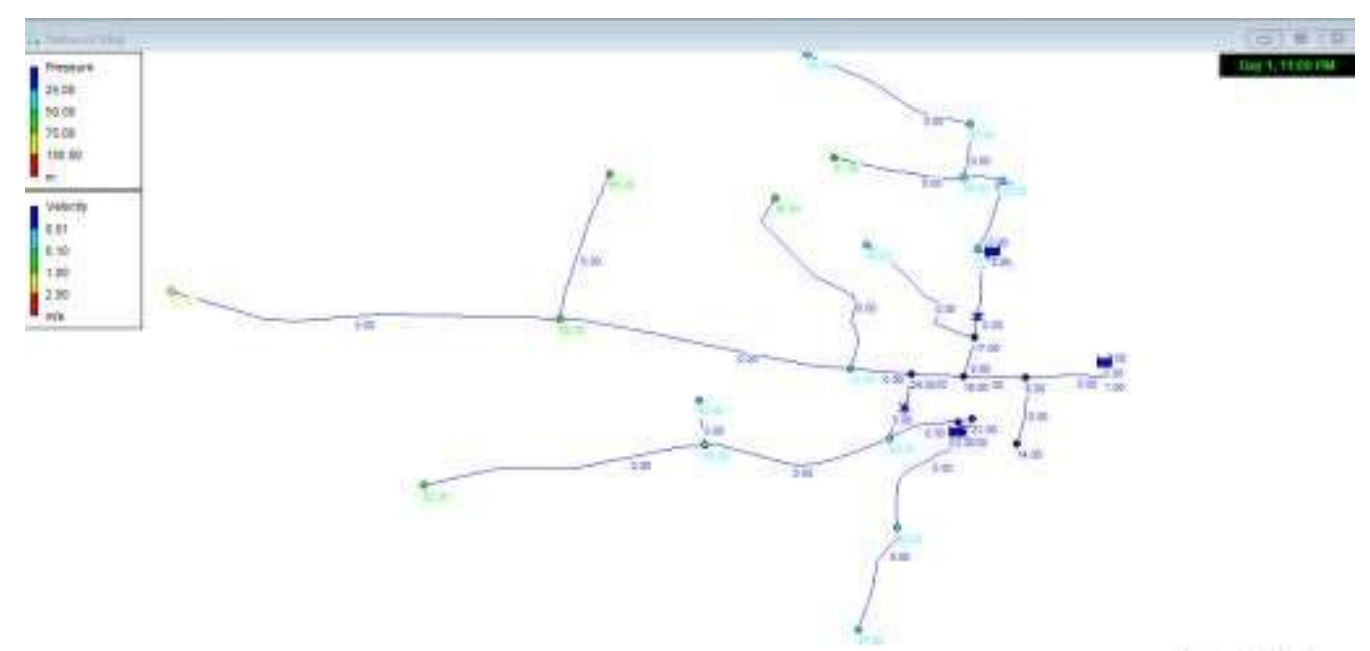

Gambar 10. Analisis EPANET 2.0 Pipa Distribusi pada Konisi Pompa tidak Beroperasi Sumber: Analisis Penulis, 2020 
Jurnal SEOI - Fakultas Teknik Universitas Sahid Jakarta

Vol 2 edisi 2 tahun 2020

\subsection{Kegiatan Pemeliharaan dan Rehabilitasi}

\subsubsection{Perbaikan Kebocoran}

Untuk mengatasi masalah kebocoran atau kehilangan air yang terjadi, PERUMDA Air Minum Tirta Jungporo sejauh ini belum memiliki program khusus untuk menangani kebocoran. Usaha yang dilakukan dalam memperbaiki kebocoran masih mengandalkan laporan dari pelanggan jika ada permasalahan pada airnya dan kemudian melaksanakan perbaikan pada titik kebocoran.

\subsubsection{Pemeliharaan Jaringan}

Sistem pemeliharaan jaringan transmisi maupun distribusi yang dimiliki PERUMDA Air Minum Tirta Jungporo belum dilakukan secara rutin atau terjadwal. Pemeliharaan atau perbaikan hanya dilakukan jika sudah terjadi kerusakan. Hal ini dapat menghambat proses produksi dan distribusi jika terjadi kerusakan pada perlengkapan yang penting. Namun, untuk menghindari hal tersebut terjadi, perlengkapan yang penting seperti pompa akan diganti sesuai umur pakainya, jika sebelum umur pakainya belum habis tapi terjadi kerusakan maka penggantian pompa akan dilakukan dengan segera.

\subsubsection{Keluhan Air Kecil/Mati}

Apabila terjadi permasalahan mengenai kontinuitas air pada pelanggan, biasanya akan dilakukan pengecekan terlebih dahulu di daerah tersebut apakah terjadi kerusakan pada jaringan distribusi atau tidak, jika terjadi kerusakan pada jaringan maka akan segera dilakukan perbaikan. Jika tidak terdapat kerusakan pada jaringan, bisa ada indikasi pada daerah tersebut ada yang menggunakan pompa untuk menyedot air yang seharusnya mengalir secara merata. Selain itu, dalam usaha untuk mencapai kontinuitas pengaliran air, PERUMDA berupaya untuk menjadikan jaringan yang awalnya dari sumur langsung dialirkan ke pelanggan akan diubah dari sumur ditampung terlebih dahulu pada reservoir setelah itu baru akan dialirkan ke pelanggan. Hal ini dilakukan agar tetap bisa menyediakan air pada pelanggan saat pompa yang digunakan untuk mengambil air dari sumur dalam sedang dalam posisi istirahat.

\section{Kesimpulan}

Berdasarkan hasil dan pembahasan pada bab sebelumnya, dapat diambil kesimpulan sebagai berikut:

1. Kondisi eksisting sistem transmisi dan distribusi air bersih, meliputi:

a. Sumber air yang digunakan pada wilayah pelayanan IKK Batealit adalah sumur Mindahan 1, sumur Mindahan 2, sumur Mindahan 3, dan sumur Bringin air yang digunakan pada wilayah pelayanan IKK Batealit adalah sumur Mindahan 1, sumur Mindahan 2, sumur Mindahan 3, dan sumur Bringin 1

b. Bangunan reservoir yang digunakan berjenis ground reservoir dengan kapasitas $350 \mathrm{~m} 3$ dan kapasitas tersebut sudah memenuhi kebutuhan air

c. Sistem pendistribusian air yang digunakan pada wilayah pelayanan IKK Batealit adalah gabungan dari sistem branch dan loop dengan sistem pengaliran gabungan gravitasi dan pompa

d. Persentase pelayanan PERUMDA Air Minum Tirta Jungporo pada wilayah pelayanan IKK Batealit mencapai 33,9\% dengan kebutuhan air tiap orang mencapai 102 liter/orang/hari

e. Perbandingan kebutuhan air domestik dan non domestik adalah 92,8\%: 7,2\%

2. Sistem transmisi dan distribusi air bersih, meliputi:

a. Kualitas air yang digunakan sudah memenuhi baku mutu sesuai dengan Permenkes No. 492/MENKES/PER/IV/2012 
Jurnal SEOI - Fakultas Teknik Universitas Sahid Jakarta

Vol 2 edisi 2 tahun 2020

b. Tingkat kehilangan air pada wilayah pelayanan IKK Batealit di tahun 2019 sebesar $31,97 \%$

c. Kelengkapan pada jalur transmisi masih kurang lengkap. Karena, belum memiliki aksesoris seperti katup pelepas tekanan, katup pelepas udara, katup penguras, dan katup ventilasi udara berdasarkan Perarturan Menteri PU Nomor 18/PRT/M/2007

\section{Daftar Pustaka}

Ditjen Cipta Karya Dinas PU. (1996). Pedoman Perencanaan Sistem Penyediaan Air Bersih. Peraturan Pemerintah Nomor 122 Tahun 2015. Tentang Sistem Penyediaan Air Minum.

Peraturan Menteri Kesehatan RI Nomor 492/MENKES/PER/IV/2010. Tentang Persyaratan Kualitas Air Minum.

Peraturan Menteri Kesehatan RI Nomor 416/MENKES/PER/IX/1990. Tentang Syarat-syarat dan Pengawasan Kualitas Air.

Peraturan Menteri Pekerjaan Umum Nomor 18 Tahun 2007. Tentang Penyelenggaraan dan Pengembangan Sistem Penyediaan Air Minum. 